\title{
THE EMERGENT ADULT: TRANSITION FROM SCHOOL TO WORK
}

\author{
SERGIU-LUCIAN RAIU \\ Postdoctoral researcher, Doctoral School Of Sociology, Babeș-Bolyai University, Cluj-Napoca, Romania
}

(C) 2019 Sergiu-Lucian Raiu

This is an open access article distributed under the Creative Commons Attribution-NonCommercial-NoDerivs license (http://creativecommons.org/licenses/by-nc-nd/3.0/)

DOI: 10.1515/eras-2019-0009

\begin{abstract}
This article approaches the topic of the emerging adulthood with young people in Romania, as well as the beginning of the first work experience. The main aim is to identify the factors of a successful transition from school to independent life. The article examines the social status and the issues the young people in Romania face with regard to the transition from education to employment. The data type longitudinal panel study refers to the cohort of young people born in 1994-1995, the generation which graduated from the $12^{\text {th }}$ or $13^{\text {th }}$ class in 2012 . We answer the question ,Which are the factors that determine the first work experience for Romanian young people and what does this look like?" Half of the young people have work experience $-50.1 \%$, with $25.2 \%$ working at the time they filled in the questionnaires, two years after graduation. Employment is explained to an extent of $1 \%$ by gender and area of residence, $4 \%$ by factors of social exclusion and $1 \%$ by factors related to negative life events. All these factors explain the variance of $6 \%$ in the employment of young people. Linear regression analysis (hierarchical) showed that social inclusion factors have the greatest effect on employment, with $4 \%$ of employment variance explained by social exclusion factors, while the influence of the demographic variables, factors of social exclusion and factors related to negative life events explain $6 \%$ of the youth employment variance.
\end{abstract}

\section{Keywords}

young people; emergent period; social exclusion; first work experience; successful transition from school to work

\section{Introduction}

In order to see what influences youth decision to have a work experience in early adulthood, our approach is structured as follows: description of variables used in the statistical analyses interpreting the work start of youth through various explanatory variables analyzing the results. We try to answer the following research question: ,, What are the factors which influence youth work start?" We proposed the following objectives: (1) to examine the emerging adult's lifestyle in Romania through their first work experience, (2) to study how some young people manage to combine studies with work and (3) to describe the causative factors that may explain the beginning of work (high school graduation by passing Baccalaureate/ Bachelor's Degree exam) and further education after graduating high school by following training courses, post-secondary schools or a form of higher education and/ or employment), the individual and family factors (parents' low intensity of work, assessment of living standards, socio-economic, material deprivation, education level of parents, gender, urban/ rural areas) and psychological factors (self-esteem, optimism, life satisfaction, depression, etc.).

The transition to adulthood is perhaps the most complex stage of the lifecycle. It is an intense period for young people who experience important life events such as enrollment in 
college (... or long-distance learning), getting a job (full or part-time), the transition to independence from the family home, debut of sexual life, marriage and childbirth. Achieving these goals will take routes that are longer and more varied than in the past (Papalia et al. 2010). The order and duration of these transitions varies, no longer having a standard character - some even became reversible, being influenced by economic, political and cultural conditions of the societies where the young people live. Compared to the last two or three decades, the transition to adulthood has become longer (extended), complex, risky, individualized, polarized and it renders finding a balance in life more difficult. Young people graduate school, enroll in work, become independent, get married and become parents much later than the previous generations. We can speak about the existence of late adolescence and late adulthood (Kehily, 2007).

Although the process of becoming mature starts earlier, adulthood is reached later on. Young people today live an extended adolescence all over the world. The young people cannot or do not want to assume the responsibilities of an adult person. Those who want or have to find a job during high school or right after graduating high school change their jobs more frequently between 18-30 years, because at this age, as far as employment is concerned, they are more unstable than in any other period in life. Some young people who have moved away from their parents' house come back and oscillate between dependence and independence due to frequent change of jobs or their life situation, thus getting married or becoming parents much later than their parents did. The phenomenon of changing the "maturity schedule" has become increasingly frequent in many cultures for some decades - the traditional criteria of becoming mature are met much later: graduation, financial independence, leaving parents' home, marriage and assuming the parent role. And this happened maybe because, as Arnett (2001) mentioned, an increasing number of young people experience a "sense of possibilities" meaning that they explore their own identity more profoundly than they did during adolescence. The phenomenon of "extended adolescence" influences the social services in different countries as it happened in the case of adolescence ${ }^{1}$ which proved to be a distinct stage in life for people from various cultures and societies. Educational and medical institutions, as well as laws have been changed in order to protect the needs of people aged between 12-18. In any society young people's entry into adult life is regulated by law which vary from one society to another, but nowadays this moment has a major importance because, when reached, it confers full legal rights. Thus, there is the voting age ${ }^{2}$, marriageable age or the age when they can have consensual sexual relationships, legal drinking age ${ }^{3}$ or legal smoking age or driving age.

For youth the opportunities to explore their identity and to experience emotions are more accessible today than ever, with a de-standardization, a deinstitutionalization, the individualization of the life course, and young people have the opportunity to create their own

\footnotetext{
${ }^{1}$ Since the publication of Mead's famous study Coming of Age in Samoa (1928), scientists from various fields have agreed that adolescence as a stage of life or as a stage of development is biologically programmed 216 years in countries such as Austria, Bosnia, Brazil, Guernsey, Isle of Man, Jersey, Nicaragua (in Germany, and Switzerland for local elections), 17 years in East Timor, Indonesia, Sudan, Seychelles (in Israel for local elections) and in some US states. Source: http://youthrights.org/issues/voting-age/voting-age-status-report/, accessed on 6.11 .2015

${ }^{3}$ In most states the age is 18-19 years, but this varies in case of states which prohibit drinking at any age (Afghanistan, Iran, Kuwait, Libya, Maldives, Mauritania, Pakistan, Qatar, Saudi Arabia, Somalia, Sudan, United Arab Emirates, Yemen), others that do not impose a legal minimum age (Bolivia, Cambodia, Cameroon, China, Indonesia, Kosovo, Sierra Leone etc.) ,in countries where age ranges from a 10-15 years threshold (Antigua and Barbuda, the Central African Republic), 16-17 years (Austria, Belgium, Cyprus, Germany, Morocco, Portugal, Spain, Switzerland, Dominica, etc.) to countries where the minimum age is 21 years (Iraq, Mongolia, Equatorial Guinea, Samoa, Sri Lanka, USA),
} http://apps.who.int/gho/data/node.main.A1145?lang=en?showonly=GISAH, accessed on 6.11.2015. 
biography (Buchmann, 1989) without following a certain pattern of life course events. The age young people assume adult responsibilities varies in modern, industrialized countries (for example, when they choose to marry, become parents or get a full time job), in the way they relate to the future (with optimism or concern), in their way of life (living with parents, roommates, romantic partners or alone), in their educational and professional interests as well as in their behavior (may engage in risky behaviors such as drug and alcohol abuse or unprotected sexual intercourse). Influenced by the social environment in which they grow, for some young people transition can be smooth, while others can experience age crises. Crises are caused by unpredictable future, by the conflict between expectations and reality, by their lack of experience or clear plans and support from peers and governments regarding social policies for youth often evaluated as insufficient and/ or lacking outcomes (Robbins and Wilner, 2001).

\section{Young people - a social problem?}

This specific period of transition from adolescence to adulthood has become more different and more difficult to overcome and the way in which the young people understand it and how they adopt views, options and behaviors different from the previous generations is intended to define the young people as a social problem. The meaning of the term "youth" varies in different societies around the world. The United Nations defines "youth" as people between 15 and 24 years, African Youth Charter defines "youth" as people between 15-35 years and according to Romanian laws the youth are active people between 14-35 years (350/21/7/2006 Youth Law, Art. 2 Para. (2) a.

The demographic changes in the last 25 years affect young people in terms of starting a family, getting an education or finding a job. Almost one in five young people in the age group 18-24 years did not complete compulsory education (17\%) and over half of the students fail to graduate $12^{\text {th }}$ grad and pass the Baccalaureate (UNICEF, 2014). The average age for first marriage increased progressively in Romania in the last quarter of the century, from 25 years in 1990 to 29.9 years in 2013 and the average age of the mother at birth has also increased progressively from 22.3 years, as it was in 1990, reaching 26.5 years in 2013 (NIS 2015). Half of the men who left home during the communist period were under 24 years, today the percentage is only reached at the age of 26 years (Mureșan, 2012). If inactive or unemployed, there is a high chance that the young people do not have the means to live more independently and are likely to continue living with their families, postponing starting a family of their own (EC, 2012, SWD 409 final). In 2014 the unemployment rate among young people (15-24 years) in the EU-28 was $21.9 \%$. In the EU, 15 countries are experiencing unemployment rates exceeding the EU average including Romania (24\%), the situation is alarming in countries like Spain and Greece, where $50 \%$ of young people aged $15-24$ years do not have a job $(53.2 \%$ and 52.4\%) (Eurostat, 2015).

The studies about culture and subculture of young people developed in the Chicago School, exploring in particular the acts of delinquency among young people, seen as a set of collective behaviors (collective set of behaviors) organized in and through subcultural class values (subcultural class values) (Barker, 2008). So, the period of transition from adolescence to young stage is a period involving major changes in the life of any person. When traversing this period, the changes may cause difficulties and prevailing is a task that requires an effort from the young people, but also it could be a task for society to find a solution. We have shown that despite these changes and challenges young people today live in a world of unlimited possibilities and can also live and lead their lives as they consider and maybe because they do not know what to do with this freedom many of them reach maturity unfulfilled.

Adolescence is a period between 14-18 years. It is seen as a critical stage because people at this age constantly try to compare to others as an autonomous person, with the consciousness 
of their own identity, but this status is not recognized by the family and peers, and this situation leads to age-related problems such as the tension between young people and society, gaining independence from parents; career choice and lifestyle. Youth is the period between 19-25 years, a period of transition from childhood dependence to adulthood independence. Every young person has to understand that society is compelled to play social roles, has duties and responsibilities, which they will have to assume sooner or later.

\section{Social inclusion of young people}

The youth's problems are mentioned as they appear in the official statistics, but also in program documents as well as in global, European and national reports. Statistical data (national and European) show the difficulties young people face such as low participation in education, school dropout, young people not enrolled in any form of education, training or employment, the difficulties in planning and insertion of young people in the labor market, the chronical unemployment, the insufficient programs that facilitate youth access to employment (volunteer programs, internships, etc.). These phenomena are experienced by a growing number of young people due to various causes (personal choices, unstable family socio-economic status, difficult social context, etc.) so they fail a successful transition to maturity. The difficult situation is also reflected in official EU institutions' documents, which, despite the adopting in the recent years a series of measures, programs and projects for social inclusion of young people, haven't proved their effectiveness yet.

The difference between Early school leavers and NEET young people is that, if the first term refers to a narrower category of young people (18-24 years old), NEET youth include a wider age group (15-29). The term "Early School Leavers" refers to the rate of early school dropout of young people between 18-24, who have completed secondary education and are not currently enrolled in any form of education or training but are on the borderline between the responsibilities of the two systems, the initial training and ongoing education (ISE 2009). According to EU, NEET (Not in Employment, Education or Training) is the term that defines young people out of a form of education, training or employment. In terms of statistics NEET rate represents the percentage of the population in a particular age (usually 15-29 years), men or women, who are not employed or enrolled in an educational program or training (Costache et al., 2014).

Nowadays employers and companies seek service-oriented youth with clearly defined abilities and skills, who understand the requirements and expectations of employers, young people showing ethical behavior, a great desire to work, ambition to learn, who are punctual and honest and show appropriate behavior. Factors such as opportunities, relationships, socioeconomic status of parents influence the least the career development, more important being their qualities and skills. Education and labor market experience are the most important types of human capital. The level of education and the workplace become part of human capital, which could increase with growing labor market experience and age. One hypothesis is that those lacking human capital, such as young people with a low level of education and/ or inexperienced, feel the impact of globalization more intensively in modern societies; part of them having a situation of precarious, flexible and uncertain employment (e.g. fixed-term contract, part-time job or irregular hours of work). On the other hand, those with higher education or "knowledge workers" have more favorable experiences. Globalization accentuates or even produces inequality providing better opportunities for highly educated youth and limits the chances of less educated ones (Schoon \& Silbereisen, 2009).

Young people have an optimistic view on their lives. They intend to become autonomous and financially independent, work representing for them fulfillment and material security. Though they hardly find a job which meets the requirements and their professional 
training they are often willing to work in other areas than those they were prepared for and feel insecure, which does not allow them to be independent and to start a family. If for those without any work experience the financial aspect is paramount, those with work experience value work relations and professional development the most. Forced to earn a living some young people are leaving school, often abandoning it for good. Although the family represents the most important support in all major decisions in life, young people nowadays often make decisions independent of someone's influence. Among young people the option to appeal to specialized institutions/ agencies placing the labor force is used less, more often they are seeking a job on the Internet, in newspapers, jobs portals while admitting that often the information is ambiguous, incomplete or inconsistent with reality. They have a perspective of a system which is defined by corruption and nepotism.

There are studies which prove that there are teenagers who work from an early age. One possible reason for this situation is that young people from socially disadvantaged families, rural families with several children, families where neither parent is employed, families where parents have only primary education, or families with health problems or with fewer goods and little cultural facilities are forced to work (Negreanu and Ionescu, 2006).

The results obtained by questioning people who managed to make a career show that external factors such as opportunities, relationships, socio-economic status of parents have influenced least the development of their careers, more important being their specific qualities and skills. Qualification and competence are still decisive factors in finding a job, but new elements have emerged: initiative, creativity, flexibility, autonomy, dynamism, responsibility etc. (Brigitte, 2005).

Internships and volunteering, including entrepreneurship are opportunities that young people take into account in order to develop life skills and improve their employment perspectives. Their attitude is to be active rather than "to stand still". They realize that perseverance, experience and enthusiasm seem to be qualities from which they will benefit in the future (UNYWR, 2011).

\section{Theories on the transition from adolescence to adulthood}

Various theorists representing different psychological and sociological theories explain the factors that influence the transition from adolescence to young adulthood. There are taken into consideration general theoretical perspectives from the traditional ones such as structuralist-functionalism, interactionalism theories on social inequalities, resilience to the latest holistic view which summarizes the points of view of various classic theories such as the interactionist-eco-developmentalist, ecological systems theory, or the life course theory and rational choice theory. All these theories mention the socializing role of the family, of school and the general influence of socio-economic, cultural, and contextual on the development of a person, referring to the importance of the personal role in managing life in a personal manner by choices and abilities to face life events. The transition from school to work is also taken into consideration, as well as career theory. Authors such as Settersten, Furstenberg and Rumbaut (2005) adopted a functionalist perspective suggesting that emergent adults postpone assuming adults 'role until they are ready. The functionalists have a positive perspective on late transition of young people to adulthood because in this period the needs of emergent adults are fulfilled.

Using conflict perspective Allahar and Côté (1994) explains that nowadays young people need more education for some jobs than it was necessary for the same jobs in the past, referring to this trend as credentialism. They also claim that the extended transition of young people aims to exploit the emerging adults. Young people are excluded from the adult society by being regarded only as consumers and possibly income workers with a minimum wage in a youth culture. Young people spend more years in school because the reorientation of the 
economy means fewer available jobs in the traditional areas of employment for young people. Conflict theorists argue that society theory exploits young people by refusing them the desire to work and thus disadvantaging the adults, so that they cannot gain financial independence from their family and do not have access to all the benefits of the society (Holloway et al., 2010). The theory “Maintaining maximum inequality" (MMI) suggests that social environment may be more important for later educational transitions than for earlier ones. This is the difference between the theory of maintaining maximum inequality and life course perspective. If life course theory stresses that small children are becoming more independent from their parents, MMI theory emphasizes that adolescents' independence depends on socio-political and social support in order to achieve certain levels of education (Lucas, 2001). The theory of hinged mobility points (Rosenbaum, 1976) explains the very low chances of students' mobility emphasizing the conceptual and institutional supports in following a certain path. Lucas (2001) proposed the theory of effectively maintained inequality (EMI). The central idea of EMI theory to achieve a certain level of education is that when globalizing educational levels, social environment will distinguish between social classes (Lucas, 2001). The life course theory postulates that the relationship between a parent and the child changes over time as the child grows old. Both EMI theory and MMI theory explain class competition between families, but MMI theory suggests that when any level of education becomes universal, the competition will not exist (Lucas, 2001). By contrast, the EMI theory postulates that for those levels of education that become universal, the competition will take place for the type of education that aims to be achieved. Both theories predict the effect of the social environment in achieving certain educational levels which are not universal. The concept of "structured individualization" refers to the fact that people have access to various resources and opportunities in life, but social inequalities are reproduced by taking individual decisions, such as, for example, if a teenager decides whether to continue studies or leave the education system (Schoon and Silbereisen, 2009). If in the adolescents' middle-class families there is a tendency to provide economic support to children till adulthood, working class parents do not offer much financial support to their children mainly because children start working in mid-adolescence, but later tend to offer support in raising children or in other things of everyday life (Schoon and Silbereisen, 2009). Although universal and pervasive stratification is present from the most simple and homogeneous societies to the most diverse and heterogeneous systems because they are all made up of vertical divisions based either on gender, age and structure of the family, or on material wealth, power and reputation (Boudon, 2006). In Romania the class structure is not stable, social class differences are not so big and there are variations within each social class in terms of parental values. The aspiration of children to continue school education depends on mother's level of education and mothers take part in a significant number in educating their children and educational styles are dependent on this (Negreanu and Ionescu, 2006).

Studies on transitions to adulthood in Europe often adopt conceptualization of becoming mature according to Arnett's theory, but also on life course perspective. Developmentalist theories or life course theories emerged in the 50s, analyzing the behavior of large groups of people over a long period and explaining psychological development in family, community and social context. Promoters such as Erikson; Loevinger; Lenvinson; Arnett assume that people's behavior derive from changes caused by internal psychological life situations. The results of the transition depend on the opportunities and structural limitations, but also on individual resources. The transition to adulthood is a development stage requiring psychological abilities, social skills and activism. The transition marks an intense period of life with transition events that accumulate and partly overlap with long-term effects which have a major importance for the future life course (Buchmann and Kries, 2011). Jane Loevinger's theory of ego development shows that the progress from one stage to another is determined by the psychological clock of 
a person and not by the chronological age or the social environment. Jane Loevinger's theory of ego development explains that people begin to appreciate the wide range of appropriate role behaviors that make each person unique in this period of emerging adolescence. The family lifecycle framework, a theory developed in the mid- $20^{\text {th }}$ century postulates that young people leave the family home, become independent and then start their own family for procreation. According to the cycle of life of the family, once independence is achieved, young people adopt three tasks: forming a separate identity from that of the origin family, undertaking a career or a role at work and developing intimate relationships with others having the same age, different from family members, in order to get the emotional support and social benefit they need. These three tasks allow young adults to become autonomous in preparation to start a new family through marriage and having children. The family has an important role, the relationship between parent and child tends to become less hierarchical as soon as the youth assume responsibility for the decisions they take. As the ecological systems theory, the family life cycle focuses on the interaction between family members and their changing needs. According to Leonard Pearlin's theory of psychological distress from the 70s, the way of life that people will adopt is determined by four elements: individual characteristics such as gender, ethnicity, intelligence, family status, personality and education; range of skills to deal with stress; availability of social support networks; nature and periods of stress requiring response. The theory explains how factors such as personality, family status and the resilience of a person (a person's ability to cope with stress) will determine how a person faces challenges. General characteristics such as ethnicity or socio-familial status influence the direction people take in life. He suggests that the availability of support from social networks, such as school, could help young people to cope with the transition (Holloway et al., 2010). The theory "Seasons of Life" (Levinson, D.J.) talks about the transition to early adulthood (17-22) which occurs at the end of adolescence when first choices for adult life are being made. In the second phase entering to adulthood (22-28) are made the first choices in love, work, friendships, values and lifestyle. Other theories worth taking into consideration are the moral development theory and the theory of the development dimensions of American psychologist Klaus Riegel.

Adolescence and youth are periods of transition which are very important for the development of healthy coping skills, but there is a high risk of engaging in unhealthy behaviors (use of narcotic substances, early sexual experiences, violence, emotional trauma and other problems) and can have dangerous effects on this period of life. Resilient teenagers adapt to a dangerous environment because of their self-confidence, their abilities to overcome obstacles and avoid dangerous situations, being able to resist the dangers they encounter or to recover afterwards. Although resilience is not universal, unconditional or a permanent quality of life (including for teenagers) it can change in time and along with shifting conditions of life. Teenagers coping with adversities are those who enjoy a "triad of protection" of resources and circumstances which lead to mental health based on the strengths of the child, family and school/community environment (Luthar, 2006). Factors that may affect the adolescents' strength are: relations with other family members, with colleagues and friends, the community and culture they grow in. For example, the relationships with family and colleagues are the most important resources for teenagers in Russia (Makhnach 2014).

Rational Choice Theory or General Theory of Rationality (GRT) assumes that the choice can be considered rational, but the behavior may be regarded as containing components inevitably irrational, which is partly caused by socio-cultural forces, which are unknown and free from any control of the person (Boudon, 2009). From the rational choice theory this research used the idea of the choices youth have made in looking for their professional direction, in choosing an educational institution. With every life event they made life choices based on their level of maturity which may be more or less rational or emotional. 
Considering current integrative theories as theories in which modern theorists try to combine views from different groups of classical or recent theories, the interactionists show that a person's personality is formed and changed through contact with others. They intend to explain the social through individual action. The ecological systems theory (Bronfenbrenner, 1979) explains how families influence the development of emergent adult's identity. According to ecological systems theory personal and family expectations, the mesosystem, are supported by ideologies and macro-system policies, but are constrained by the resources of exosystem. Hair et al., (2009) based on Bronfenbrenner's ecological theory examined the risk and protective factors from the proximal systemic environment (individual, friends, family and community) to learn how to predict adolescent risk behavior profiles.

In Social Cognitive Career Theory Lent, Hackett and Brown (1999) hypothesized that the transition from school to work is a process rather than an event that takes place gradually during the school years and which is incorporated into the larger phenomenon of career development. A successful transition, therefore, depends on how well they cope with various young professional tasks. Both concepts are seen as essential for cultivating interests, setting aims and related actions, which are also shaped by contextual influences (support from social background and impediments) (Lent et al., 1999). Based on this theory, the development of appropriate interventions to promote the road to a successful career could best be implemented throughout the school years. Also, the authors stress the importance of developing self-efficacy and competence in the most generic areas of qualification (employability skills, teamwork, leadership) that are needed to convert goals into action and to negotiate obstacles and support (Choon and Silbereisen, 2009). Another theory relates to the definition of personality in the workplace (Strauser et al., 1999) and focuses on the relationship between occupational interests, personality characteristics and possible workplace environments (Holland, 1997). Based on this theory, identifying and promoting the interests and skills becomes important for career development programs and for assistance in making career choices (Schoon and Silbereisen, 2009). There are also references to the careership theory. Choosing different career paths is largely dependent on the level of education and influenced by the social class, which is a major factor in explaining the professional path (Bates and Riseborough, 1993). Griffin (1985) introduced the gender in explaining chosen job type, and studies such as those by Blackman (1987), Cros and Wrench (1991) showed that ethnic origin restricts opportunities for some groups. Banks et al. (1992) indicated that geographical location is an important factor, due to variations in unemployment and employment opportunities (Hodkinson and Sparkes, 1997). For Bourdieu, each stakeholder brings capital (economic, social, cultural or symbolic) influencing the game. Okano (1993) speaks about resources. The same source can be positive, negative or neutral, depending on the context in which it is "used". In the transition to the labor market, other participants often hold more capital and can exercise more power than young people and the former have the resources to determine the rules. For example, employers have the power to hire and to fire, while training and education providers understand the systems better than young people and have contacts and access to networks to which young people do not have (Hodkinson and Sparkes, 1997).

In scientific literature on the transition to work a common concept is that of "career path" (Furlong 1992). Banks et al. (1992) argue that there are career advancement models that describe the route. These characteristics depend largely on youth past background, such as class, gender, ethnicity, geographical location and level of education. The trajectory is "knowable" because from the early decisions in the transition to work and as the lives grow, one climbs gradually in a direction that is clear and predictable for the knowledge of an outsider. Although the plan and the route can change, these are seen as occasional deviations when a person changes the route or refrains from a social level to another. The path from a turning point to 
another turning point may be predictable and smooth or irregular and idiosyncratic (Hodkinson and Sparkes, 1997).

\section{Methodology}

In this article we have carried out which use quantitative method it is explored the subjective and the objective perspective of one phenomenon: the beginning of work by explanation through statistical analyzes in order to identify the factors that determine a successful transition to the beginning of youth work.

Starting from the expectations of modern societies regarding young people that programmatically aim to emphasize the integration of youth into the labor market and emphasizes the importance of youth as the workforce, the research's presumed general objective is understanding the social factors that influence young people in their development to labor market by using regression models that show the explanatory power of social exclusion factors and those related to negative life events on the successful transition to adulthood and the beginning of work.

\begin{tabular}{ccll}
\hline Name & $\begin{array}{c}\text { Type of } \\
\text { research }\end{array}$ & \multicolumn{1}{c}{$\begin{array}{c}\text { Method } \\
\text { (instrument) }\end{array}$} & \multicolumn{1}{c}{ Lot/ Sample } \\
\hline $\begin{array}{c}\text { Panel } \\
\text { research }\end{array}$ & Quantitative & $\begin{array}{l}\text { Online survey } \\
\text { And/or „pen and } \\
\text { paper" questionnaire } \\
\text { after 2 years }\end{array}$ & $\begin{array}{l}\text { Total: 3509 high school students, } \\
\text { wave I (2012) representative } \\
\text { sample } \\
\text { Total: 1509 wave II (2014) } \\
\text { respondents from first wave }\end{array}$ \\
\hline
\end{tabular}

Table 1. The longitudinal research presented in this article

The data from this research come from the longitudinal study "Outcomes of Adolescence. A longitudinal perspective", the respondents filling in the online form in both waves on the project's site. The questions refer to many aspects of their lives: family, relationships and support, physical and mental health, high-risk behavior and their perspective on major events that can take place in adolescence. The collection of first data took place between October 2012 and February 2013 in 33 localities in the country (from Bihor, Sălaj, Cluj, Sibiu, Covasna, Iași, Bacău, Galați, Constanța, Argeș, Teleorman, București, Ilfov, Dolj, Vâlcea, Timiș, Caraș-Severin counties). The type of sample is random, multistage stratified (four stages of sampling: area, counties, schools, classes). The first wave (2012) consists of 3509 high school students, nationally representative sample (high school students in final year of high school, average age 18.06 years), $58.1 \%$ female and $58.4 \%$ representing youth from urban areas. Young people from $1^{\text {st }}$ wave have been invited to complete the new online questionnaire on the project site. Response rate was $43 \%$ of young people from first wave, the average age 20.04 years. $59 \%$ female, $61.9 \%$ urban, $97.1 \%$ unmarried, $99.1 \%$ have graduated high school, $90.8 \%$ have passed the Baccalaureate, $0.7 \%$ are parents (11 people), $82.4 \%$ continued their education after high school, mostly high education studies (74.8\%). $49.4 \%$ had no jobs when filling in the questionnaire, two years after graduation. 


\begin{tabular}{|c|c|c|c|c|c|c|}
\hline & & $\begin{array}{c}\text { Wave } \\
2012-2013 \\
\text { (no) }\end{array}$ & $\begin{array}{c}\text { Wave } \\
1 \%\end{array}$ & $\begin{array}{c}\text { Wave II } \\
\text { 2014-2015 } \\
\text { (no*) }\end{array}$ & $\begin{array}{c}\text { Wave II } \\
\%\end{array}$ & $\begin{array}{c}\text { Percentage } \\
\text { Wave II/ } \\
\text { Wave I } \\
(\% * *)\end{array}$ \\
\hline \multirow[t]{2}{*}{ Gender } & Girls & 2043 & 58.1 & 891 (-1152) & 59.0 & 43.6 \\
\hline & Boys & 1466 & 41.9 & $618(-848)$ & 41.0 & 42.1 \\
\hline \multirow[t]{2}{*}{ Residence } & Urban & 2030 & 58.4 & 934 (-1096) & 61.9 & 46.0 \\
\hline & Rural & 1445 & 41.6 & $575(-870)$ & 38.1 & 39.7 \\
\hline \multirow{2}{*}{$\begin{array}{l}\text { High school } \\
\text { from area }\end{array}$} & Urban & 2962 & 85.7 & $1389(-1573)$ & 92.4 & 46.8 \\
\hline & Rural & 493 & 14.3 & $114(-379)$ & 7.60 & 23.1 \\
\hline \multicolumn{2}{|c|}{$\begin{array}{c}\text { Material deprived } \\
\text { family }\end{array}$} & 610 & 19.5 & $236(-374)$ & 16.6 & 38.6 \\
\hline \multicolumn{2}{|c|}{ Total } & \multicolumn{2}{|c|}{3509} & \multicolumn{2}{|c|}{1509} & 43 \\
\hline
\end{tabular}

Notes: *number of young people is smaller in the first wave of the study

** the percentage of total initial sample of young people who filled in the questionnaire in the second wave of the study.

\section{Table 2. Socio-demographic characteristics of the samples from the two waves of the study}

The questionnaire included questions on youth first work experience. Questions addressed occupational status, work experience during their studies, type of first work experience (practice, voluntary, formal or informal employment), manner of employment at first job, remunerated or not, satisfaction on salary, number of hours worked per week, willingness of employers to accept flexible working hours, type of employment contract, compatibility of job training education, the salary, intention to involve the following year, period of looking for a job, participation at interviews and reasons why young people do not have a job.

\begin{tabular}{ccc}
\hline & $\begin{array}{c}\text { WITHOUT } \\
\text { work experience }\end{array}$ & $\begin{array}{c}\text { WITH } \\
\text { work experience }\end{array}$ \\
\hline Passed Baccalaureate* & 53.5 & 46.5 \\
Didn't pass Baccalaureate & 24.2 & 75.8 \\
\hline Total & 706 & $\mathbf{6 8 4}$ \\
\hline
\end{tabular}

* figures express the percentage, the total number

Table 3. Work experience based on Baccalaureate success

\section{Results}

From the young people in the sample $99 \%$ have successfully graduated high school. The vast majority (96.8\%) took the Baccalaureate exam and $90.8 \%$ passed it. From the $17.6 \%$ who do not attend any form of education, $25 \%$ said they wanted to start work, $23.4 \%$ failed the exam because they did not feel ready, 21.5\% mentioned economic reasons (not had resources, money), $14.8 \%$ had to work to support themselves, while $5.9 \%$ said that level of education is sufficient. From the $82.4 \%$ who continue their education, the majority (90.8\%) are college students and 9.2\% attend a form of post-secondary education. Most of them (86.2\%) are supported by parents, not necessarily financially, to cope in everyday life. $56.8 \%$ of young 
people are interested in pursuing a master's degree abroad. $65.7 \%$ say that after graduating current educational program would like to look for (another) job, while $31.7 \%$ would like to continue their education. Half of young people have work experience $50.1 \%, 25.2 \%$ working at the moment of filling in the questionnaires, two years after graduation. Of these $46.2 \%$ were employed on the first job through an interview/ competition, $37.5 \%$ were hired with the help of a recommendation from an acquaintance/friend, while for $11.4 \%$ of them parents found them a job. $76.5 \%$ worked/are working to earn money, $20.7 \%$ to gain experience. Most of them say that the activity of the workplace is not related to their specialization $(79.2 \%)$ and $20.8 \%$ said that it is. $60.6 \%$ of them say that the job did not help/ does not help achieve career related plans and $39.4 \%$ say it did. In our sample, the majority are students, the percentage of those who were in an interview in the previous month is small: $8.3 \%$ were in an interview in the previous month, looking for a job for an average of 5 months. Among the reasons for not having a job, $97.8 \%$ of young people stated they do not want a job now, 96.6\% mentioned school or a training program attendance, $83.8 \%$ say employers consider them young and inexperienced, $67.1 \%$ said their families do not want them to work, $65.7 \%$ of young people are not interested in the jobs they can get, $56.9 \%$ do not know how to find a job, 55.8\% say that there is no job available for their specialization, $41.5 \%$ say they have given up the search because no one helped them when they tried to find a job.

In the category demographic variable are included gender and area of residence of the young person. In the category of social exclusion variable are included material deprivation, income poverty, low labor intensity and parents' education and perception of family's social status. The independent variable related to negative events of life refers to the following events over which the young man has no control or influence: injury, serious illness or death in the family, unemployment or deterioration of parents' financial status, robbery of personal property, excessive consumption of tobacco, alcohol, drugs in the family, a relative in prison, homelessness, family separation, witnessing violence or disasters which have serious lifethreatening consequences.

For each of the five dependent variables which measured the successful transitions from school to work we designed three linear regression models (hierarchical) introducing sequentially in blocks in each of the steps (model) control variables. Thus, in order to see how the variance of the dependent variable (one at a time from successful transition from school to work) is explained by variables (control factors, indicators): demographic, social exclusion and the influence of negative events of life, we have sequentially introduced these in the three regression models. In the first model we introduced demographic variables (gender, place of residence) to see the influence of their effect on employment. In the second step, we introduced a second group of factors to see how much explanatory power indicators of social exclusion have, controlling the demographic variables. In the last step we introduced the composite factor comprising those negative life events on which the young person has no control but which, we assumed, may influence (negatively) the successful transition from school to work.

Employment is explained to an extent of $1 \%$ by gender and area of residence, $4 \%$ by factors of social exclusion and $1 \%$ by factors related to negative life events. All these factors explain the variance of $6 \%$ of the employment of young people.

Linear regression analysis (hierarchical) showed that the greatest effect on employment is that of social inclusion factors, $4 \%$ of employment variance is explained by social exclusion factors. The influence of the demographic variables, factors of social exclusion and factors related to negative life events is explaining $6 \%$ of the youth employment variance.

Table 4. shows how the explanatory variables introduced in the models of hierarchical linear regression explain the work experience of young people, the power of the explanatory effect being smaller (of $0.1 \%, \mathrm{R}^{2}=0.01$ ) with an increase up to the final step of model $3(0.6 \%$, 
$\left.\mathrm{R}^{2}=0.06\right)$ when in the analysis there were introduced all the variables. Significant effects on young people's starting a job are shown by such variables as gender, the superior education level of the parents, financial poverty, and the subjective perception on the family's status and the existence of negative events in which the young did not have an active role. The greatest influence on young people's getting a job is the education level of the parents $(B=-0.184)$. The low intensity of work within the family has a significant effect in regression model $2(B=0.218$; $\mathrm{p}<0.05)$, but once the variable of negative events' presence without the young's involvement is introduced, the significant effect of the former variable disappears. The boys with parents who do not have higher education, young people in situations of financial poverty, those who have a worse perception on the financial status of the family and those who have experienced negative events (could be unemployment or worsening of the financial status of the parents, but also the other negative events) are those who tend to have a work experience even from the beginning of youth.

\begin{tabular}{|c|c|c|c|c|c|c|c|c|c|}
\hline & \multicolumn{3}{|c|}{ Model 1} & \multicolumn{3}{|c|}{ Model 2} & \multicolumn{3}{|c|}{ Model 3} \\
\hline & $B$ & St. error & sig. & B & St. error & sig. & $B$ & St. error & sig. \\
\hline (Constant) & 1.755 & 0.046 & 0.000 & 1.916 & 0.127 & 0.000 & 1.830 & 0.128 & 0.000 \\
\hline Gender ( $0=$ male) & -0.146 & 0.046 & 0.002 & -0.141 & 0.045 & 0.002 & -0.143 & 0.045 & 0.002 \\
\hline Residence ( $0=$ rural) & -0.143 & 0.046 & 0.002 & -0.035 & 0.049 & 0.468 & -0.054 & 0.048 & 0.267 \\
\hline Severe material deprivation $(0=$ not $)$ & - & - & - & 0.050 & 0.063 & 0.424 & 0.036 & 0.063 & 0.567 \\
\hline Parents' education - secondary & - & - & - & 0.029 & 0.088 & 0.742 & 0.012 & 0.087 & 0.887 \\
\hline Parents' education - higher & - & - & - & -0.169 & 0.093 & 0.068 & -0.184 & 0.092 & 0.047 \\
\hline Financial poverty $(0=$ not $)$ & - & - & - & 0.136 & 0.056 & 0.016 & 0.123 & 0.056 & 0.029 \\
\hline Low intensity of work $(0=$ not $)$ & - & - & - & 0.218 & 0.106 & 0.041 & 0.193 & 0.106 & 0.068 \\
\hline Family status perception & - & - & - & -0.040 & 0.013 & 0.002 & -0.033 & 0.013 & 0.012 \\
\hline $\begin{array}{l}\text { Negative events, NO active role of } \\
\text { young }\end{array}$ & - & - & - & - & - & - & 0.068 & 0.016 & 0.000 \\
\hline $\mathrm{N}$ & & 1376 & & & 1376 & & & 1376 & \\
\hline $\mathrm{R}^{2}$ & & 0.014 & & & 0.052 & & & 0.064 & \\
\hline Sig. $R$ change & & 0.014 & & & 0.038 & & & 0.012 & \\
\hline
\end{tabular}

Table 4. Linear (hierarchical) regression analysis for getting employed

\section{Start in work of young people and the factors that influence it}

In studying the start in work of young people we were interested in young people who reported work experiences.

\begin{tabular}{l|c|c}
\hline & Exp. (B) & Sig. \\
\hline Constant & $\mathbf{3 . 0 5}$ & $\mathbf{0 . 0 0}$ \\
Gender (subj. girl) & $\mathbf{1 . 4 7}$ & $\mathbf{0 . 0 0}$ \\
Residence area (subj. urban) & 1.07 & 0.51 \\
Material deprivation (subj. is not in a situation of material deprivation) & $\mathbf{0 . 7 1}$ & $\mathbf{0 . 0 2}$ \\
Financial poverty (subj. is not poor) & $\mathbf{0 . 5 9}$ & $\mathbf{0 . 0 0}$ \\
Intensity of work (subj. does not have low intensity of work in family) & $\mathbf{0 . 5 2}$ & $\mathbf{0 . 0 1}$ \\
\hline
\end{tabular}

Table 5. Relative opportunities of starting to work for young people ( 0 - has no work experience, 1 - has work experience)

By calculating the multiple determination coefficient $\mathrm{R}^{2}$ Nagelkerke we find that the model explains $0.4 \%$ of the variation in the dependent variable young people's start in work, which is a rather low percentage. The model helps us to remove the insignificant variables. Upon checking the exponential beta coefficients, it resulted that:

- The chance for a female to prefer a start in work as compared to the chance for a male not to prefer experimenting work in this stage of their life increases by factor 1.47 when the gender index increases with one unit, keeping under control the other variables. 
- As far as material deprivation is concerned, the change for a young person to prefer starting to work from this age as compared to one who does not prefer to start working decreases by a factor of 0.71 . Consequently, the young people whose family is not in a situation of material deprivation have lesser chances to prefer starting to work at this age.

- The situation is the same in the case of young people who are not in a situation of financial poverty, the chance for them to prefer to start working decreasing with 0.59 , so young people who are not in a situation of financial poverty have lesser chances to prefer starting to work.

- The chance for a young person who lives in a family in which the intensity of work is low (according to the Eurostat indicator) increases with 0.52 , so these young people have higher chances to prefer to start working immediately after graduating high school or even during high school.

Upon analyzing the data from the second wave of the panel research we reached the conclusion that demographic factors, such as gender and residence environment, factors related to social exclusion (severe material deprivation, financial poverty, low intensity of work in the household, parents' education and the perception of the family's own socio-economic status), but also the existence or not of negative events have a significant influence on the successful transitions to maturity (educational success, avoiding high-risk behaviors, psychological wealth, a positive perception of one's own health, employment). Thus, the greatest influence of these three factors (demographic variables, social exclusion factors, negative events) on the successful transitions to maturity is shown in avoidance of engaging in high-risk behaviors (they explain $14.9 \%$ of the variance), followed by the effect on educational success, explaining $14.4 \%$ of its variance, $12 \%$ of the perception of one's own health being explained by these three factors, and $6 \%$ of the variance of the young person's starting to work (see Fig. 1. for the influence of each factor separately).

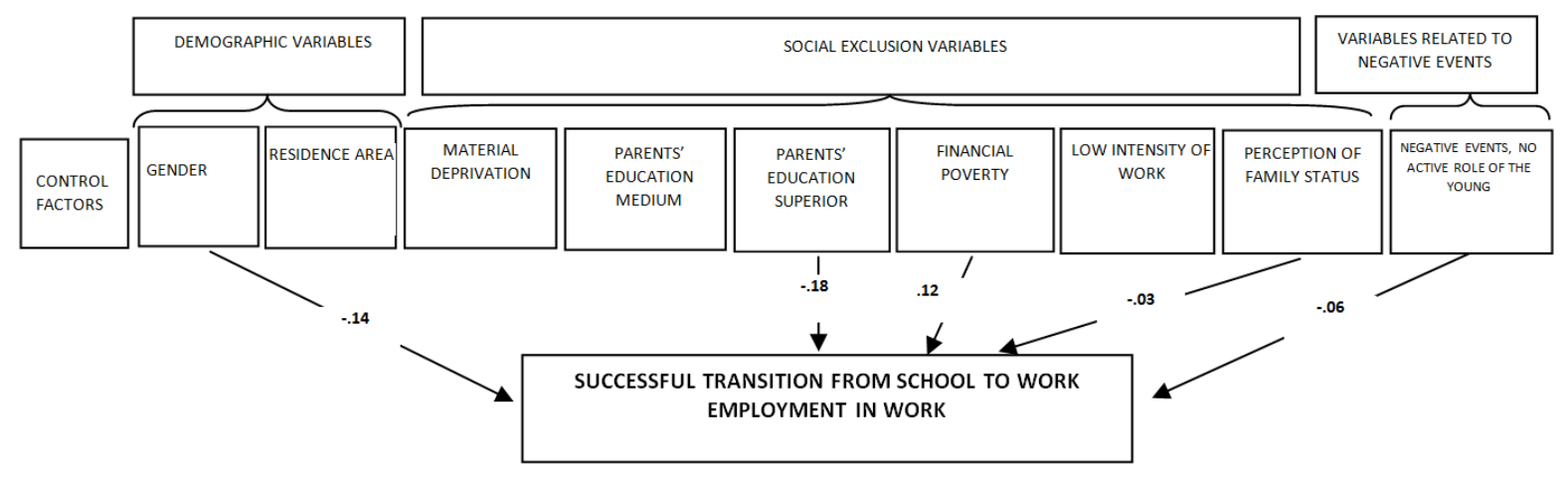

Fig. 1. The empirical diagram of the influence of the control factors on the first work experience of youth

\section{Conclusions}

The specificity of the emerging transition period was also confirmed by the studies in the project "Outcomes of Adolescence. A longitudinal perspective" (on two groups totaling the opinions of 1240 high school pupils and students) (in RESEARCH III), by using an internationally tested research instrument (IDEA: Inventory of the Dimensions of Emerging Adulthood) proposed by Arnett (2001). The results reflect internal criteria of the adult status as 
being the important maturity criteria for the young people in today's societies, rather than transition events (such as getting married or becoming a parent), the latter ranking very low among young people's options. Despite the results' showing cultural differences among the various countries, the data collected in Romania are similar to those provided by young Americans, Austrians, Greeks, and Israelis or Chinese, showing the transition to maturity is defined mainly through individual transitions, balanced partly by criteria that reflect the concern for others. A possible explanation for the similarity of young Romanians to the youth in other societies could be the current economic, social and cultural environment, with the multiple changes occurring in Romania, including the improvement of the living standard and the adopting of the individualist values and ideologies specific to Western societies.

Following the analyses on the samples in the panel studies, we studied the connection between the factors related to social exclusion and the variables characterizing the success of the transition from school to work. Based on the regression analyses, it is shown that social exclusion has the strongest effect on educational success and on starting to work.

Out of the young people who drop out of school, most of them (61.3\%) lack resources and do not believe they can combine studying with work. Alleging they had to/ wanted to work to support themselves invoking financial reasons (did not have money, resources); almost a quarter (24\%) failed their exams, while 5.9\% assert they have learned enough. Out of those who continue education, most are students and approximately $60 \%$ want to apply for a Master's degree abroad. Half of the young people have work experience, one quarter currently working - even if not in an area connected to their academic background or in a job that would help them achieve their career goals. They were employed either by taking part in a selection/ interview, or after being recommended by friends/ acquaintances, around $10 \%$ being helped by their parents to find a job. In fact, most of them have their parents' support, not necessarily from a financial viewpoint, to deal with everyday life. Most of the have worked/ are working to earn an income and $20 \%$ to gain experience. Most do not work because, they say, they study (namely, they want to dedicate themselves to studying and do not see how they could cope with both attending education and working). On the second place there is the employers' argument related to lack of experience and being too young. A significant percentage assert they do not want or their family does not want them to work, while others are not interested in jobs as they do not find openings in the fields of their specialization, or because nobody helped them to find a job. In this respect, the panel research distinguished different transition routes of the young people in the period after graduating high school to starting a professional career. Although the sample in the second wave of the present research has not maintained the national representativity as the first wave, at the level of the study on high school pupils, the young respondents' different chances that can result in starting very different professional careers and family life are still emphasized

\section{REFERENCES}

Arnett, J. J. (2001). Conceptions of the Transition to Adulthood: Perspectives from Adolescence through Midlife, $\begin{array}{llllll}\text { Journal of } & \text { Adult } & \text { Development, } & \text { 133-143, }\end{array}$ http://www.jeffreyarnett.com/articles/ARNETT_conceptions_of_the_transition_to_adulthood.pdf, accessed 28.06.2012.

Banks, M., Bates, I., Breakwell, G., Bynner, J., Elmer, N.,Jamieson, L. \& Roberts, K. (1992) Careers and Identities: Adolescent Attitudes to Employment, Training and Education, Their Home Life, Leisure and Politics (Milton Keynes, Open University Press).

Barker, C. (2008). Cultural Studies: Theory and Practice. London, Sage Publications.

Brigitte, I. (2005). Despre tendințe pe piața muncii și modalități de percepere a carierei (Trends on the Labour Market and Methods of Perceiving Career), in România socială - Drumul schimbării și al integrării europene (Social Romania - The Path to Coordination and European Integration), (coord.) Petru Ilut, Laura Nistor, Traian Rotariu, Eikon Publishing House: Cluj-Napoca, Vol. II, pp. 12-19. 
Boudon, R. (2006). Tratat de Sociologie (Sociology Treaty), Humanitas Publishing House: Bucharest.

Boudon, R. (2009). Rational Choice Theory în The New Blackwell companion to social theory, Turner Publishing House, S. B.

Bronfenbrenner, U. (1979). The Ecology of Human Development. Experiments by Nature and Design, Cambridge: Harvard University Press.

Buchmann C., Marlis; Kriesi I. (2011). Transition to Adulthood in Europe in Annual Review of Sociology, 37:481503.

COM E (2012). SWD 409 final. Document de lucru al serviciilor comisiei care însoţeşte documentul Propunere de recomandare a Consiliulului privind înfiinţarea unei garanţii pentru tineret (COM, 2012, 729 final), file:///C:/Documents\%20and\%20Settings/ealbert.ASOC/Desktop/SWD\%20Youth\%20GuaranteeRO.pdf, accessed June 2015.

Costache L. (coord.), Varly P., Iosifescu Ș., C., Fartușnic C., Andrei T., Herțeliu C. (2014). Costul investiției în insuficiente în educație în România. Raport final pentru UNICEF (The Cost of Investment in Education Insufficiencies in Romania. Final Report for UNICEF), Bucharest: UNICEF, http://www.unicef.ro/wpcontent/uploads/Costul-investitiei-insuficiente-in-educatie_2014.pdf, accessed May 2015.

Côté, J. E.; Allahar A. L. (1994). Generation on Hold: Coming of Age in the Late Twentieth Century. Toronto: Stoddart.

Eurostat, (2015). School to work transition statistics, http://ec.europa.eu/eurostat/statistics-explained/index.php/ Archive:School-to-work_transition_statistics, accessed 11.03.2015

Eurostat, (2015). http://ec.europa.eu/eurostat/statistics-explained/index.php/Material_deprivation_statistics__early_results accessed 14.09.2015.

Furlong, A. (1992). Growing Up in a Classless Society? School to Work Transitions (Edinburgh, Edinburgh University Press).

Hair, E., C.; Park, M. J.; Ling, Th., J.; Moore K., A. (2009). Risky Behaviors in Late Adolescence: Co-occurrence, Predictors, and Consequences in Journal of Adolescent Health 45 (2009) 253-261, http://ac.elscdn.com/S1054139X09001116/1-s2.0-S1054139X09001116-main.pdf?_tid=6fe3693a-5b9e-11e5-880600000aacb35d\&acdnat=1442317354_2797d5d965b29aa73fccdc8ee7eb4fe7, accessed 15.09.2015.

Hodkinson, P.; Sparkes, A.C. (1997) Careership: A sociological theory of career decision making în British Journal of Sociology of Education, 18:1, 29-44.

Holland, J. L. (1997). Making vocational choices: A theory of vocational personalities and work environments (3rd ed.). Odessa, FL: Psychological Assessment Resources.

Holloway, M.; Holloway G.; Witte J. (2010). Individuals and Families: Diverse Perspectives, http://highered.mheducation.com/sites/0070738769/information_center_view0/sample_material.html, accessed 06.11.2015.

National Institute of Statistics, (2015). TEMPO-Online Statistic Database, http://statistici.insse.ro/shop/?page=info, accessed 14.05.2015.

National Institute of Statistics, http://www.insse.ro/cms/, Tempo Database, accessed May 2015.

National Institute of Statistics, (2015). http://www.recensamantromania.ro/noutati/volumul/, accessed June 2015.

National Institute of $\quad$ Statistics, 2014$)$. https://statistici.insse.ro/shop/index.jsp?page=tempo2\&lang=ro\&context=11, accessed 18.07.2014.

National Institute of Statistics, http://www.insse.ro/cms/ accessed 10.03.2015.

Kehily M., J. (2007). Understanding Youth: Perspectives, Identities and Practices, The Open University: London.

Lent, R.W., Hackett, G., \& Brown, S. (1999). A social-cognitive view of school-to-work transition. The Career Development Quarterly, 47, 297-311.

Lucas, S., R. (2001). Effectively Maintained Inequality: Education Transitions, Track Mobility, and Social Background Effects, in The American Journal of Sociology, Vol. 106, No. 6, pp. 1642-1690, phttps://campus.fsu.edu/bbcswebdav/institution/academic/social_sciences/sociology/Reading\%20Lists/ Stratification $\% 20 \% 28$ Gender\%2C\%20Race\%2C\%20and\%20Class \%29\%20Copies\%20of\%20Articles $\% 20$ from\%202009/Lucas-AJS-2001.pdf, accessed 18.09.2015.

Luthar, S. S. (2006). Resilience in development: A synthesis of research across five decades in D. Cicchetti \& D. J. Cohen (Eds.), Developmental psychopathology: Risk, disorder, and adaptation (pp. 740-795). New York: Wiley.

Makhnach, A., V. (2014). Resilience in Russian Youth in International Journal of Adolescence and Youth, http://dx.doi.org/10.1080/02673843.2013.815116, accessed 15.09.2015.

Mureșan, C. (2012). Schimbările comportamentului familial în România. O abordare din perspectiva cursului vieții (Changes in Family Behavior in Romania. An Approach from the Perspective of the Life Course), Cluj-Napoca: Presa Universitară Clujeană.

Negreanu, E., Ionescu, M. (2006). Educația în familie. Repere și practici actuale, Institutul de Științe ale Educației (Family Education. Current Landmarks and Practices, Institute of Education Sciences: Bucharest) 
Papalia, D. E.; Wendkos, O. S.; Duskin, F. (2010). Dezvoltarea umană, (Human Development), Editura Trei, Bucharest

Rosenbaum, J. E. (1976). Making Inequality. New York: Wiley.

Settersten R. A. Jr.; Fustenberg F. F.; Rumbaut R. G. (2005). On the Frontier of Adulthood - Theory, Research and Public Policy, Chicago, IL: University of Chicago Press.

Strauser, D. R., Waldrop, D. G., \& Ketz, K. (1999). Reconceptualizing the work personality. Rehabilitation Counselling Bulletin, 42(4), 290-301.

UNICEF, (2014). Study summary "Costs of Insufficient Investment in Education in Romania", http://www.unicef.ro/wp-content/uploads/Rezumat-studiu-\%E2\%80\%9CCosturile-investitieiinsuficiente-in-educatie-in-Romania\%E2\%80\%9D-2014.pdf, accessed June 2015.

UNYWR, (United Nation World Youth Report) (2011). Youth Employment: Youth Perspectives on the Pursuit of Decent Work in Changing Times http://unworldyouthreport.org/media/pdfs/WYR2012_SummaryReport_EN.pdf, accessed 14.10.2014 